\title{
A green coffee based product and its comparasion to commercial products regarding the antioxidant capacity
}

\author{
Sousa, F.C.A. ${ }^{\text {a }}$; Souza, E.F ${ }^{\text {b }}$ Pontes, S.M. ${ }^{\text {; }}$ Leal Junior, W.F.b ; Freitas-Silva, O. $^{\text {b }}$ \\ Nogueira, R.I. ${ }^{b *}$ \\ ${ }^{a}$ Programa de Pós-graduação em Alimentos e Nutrição (PPGAN) - Universidade Federal do Estado \\ do Rio de Janeiro (UNIRIO), Brazil. \\ ${ }^{\mathrm{b}}$ Embrapa Agroindústria de Alimentos, Rio de Janeiro, R.J., Brazil.
}

*E-mail of the corresponding author: regina.nogueira@embrapa.br

\begin{abstract}
Green Coffee Products (GCP) consumption have been increased recently and is justified due its benefits to human health, as the antioxidant activity and thermogenic properties and ant mutagenic and ant carcinogenic capacity and also present alleged weight loss control. The aim this work was to elaborate a GCP with Coffea canephora by spray drying and compare its antioxidant capacity to commercial GCP samples by ORAC methodology. The results presented a range of 33.02 - 2,408.05 $\mu$ mol Trolox/g for commercial products and 1,861.91 $\mu \mathrm{mol}$ Trolox/g for the product obtained in this work.
\end{abstract}

Keywords: Antioxidant Activity;Green Coffee;Spray Drying;ORAC. 


\section{Introduction}

In recent years, the studies on the biological activity of green bean coffee and their beverages has been more encouraged and explored [1]. Green coffee beans differ in chemical composition according to species and origin. Coffee beans are composed of polysaccharides, lipids and proteins and as secondary compounds caffeine, trigonellin, chlorogenic acids, free sugars (mainly sucrose), free amino acids, diterpenes, melanoidines, among others [2]. However, during the coffee roasting process, several chemical reactions occur at the same time, from which some compounds are degraded, such as proteins, polysaccharides, and chlorogenic acids [3].

A cup of the roasted coffee drink is rich in different and complex bioactive substances, which can present antioxidant activity, being the beverage an important source of the consumption of natural antioxidants [4].

The process and formulation to obtaining food supplements from green coffee may be the differential, as the commercial products of dietary supplements based on green coffee has different formulations which uses various food materials sources of bioactive compounds. Besides the formulation and choice of raw material, since it is known that the robusta coffee beans (Coffea canephora) contains more acids chlorogenic than $C$. arabica, which plays an important role in the antioxidant capacity [5]. The product obtained in this work was composed only by green coffee extract from C. canephora and maltodextrin.

In addition to the consumption of the traditional coffee beverage made by infusion of roasted and ground coffee, green coffee extract (GCE), commercialized in different forms, such as capsules, flours or liquid extract, has gained a market share by the appeal of antioxidant activity and for the help in the weight loss process [6], since it contains 6 to $12 \%$ of chlorogenic acids, of which during the roasting process of the grain for the preparation of the traditional coffee beverage undergoes degradation [7]. In this way the aim of our study was elaborate a GCP with $C$. canephora by spray drying and compare its antioxidant capacity to commercial GCP samples.

\section{Materials and Methods}

\subsection{Green Coffee Products}

It was evaluated nine different products of commercial dietary supplements based on green coffee, purchased directly from Rio de Janeiro trade, in the form of capsules or flours and one GCP imported from USA, Figure 1A. A GCP 10 was elaborated under our laboratory conditions, Figure 1B. 


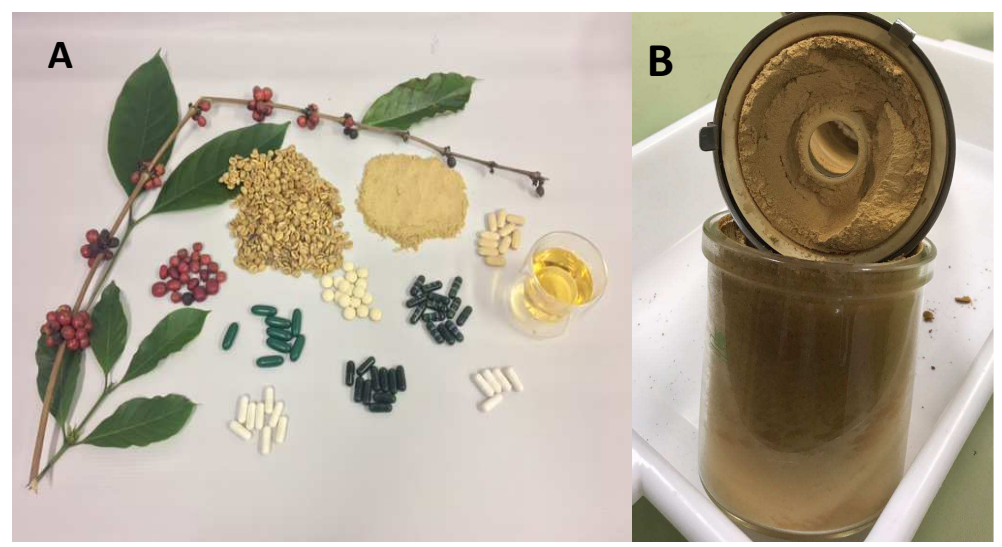

Fig. 1. Market GCP analysed (A), GCP produced by spray drying

\subsection{Extraction of bioactives compounds and production of green coffe dietary supplement by spray drying}

For extraction of bioactives compounds of robusta coffee (C. canephora) the grains were grounded in an IKA grinder (A11) and sieved (480-680 $\mu \mathrm{m})$. Then, the aqueous extract was according to a methodology adapted from Liu et al., (2010) [8], using a ratio of $0.11 \mathrm{~g} / \mathrm{mL}$ (mass/volume) between green coffee and distilled water for the extraction of bioactive compounds in Hielscher model tip ultrasound with 200 watts power for 10 minutes with a sample immersed in an ice bath. After extraction, the samples were taken to the refrigerated centrifuge ROUTINE 38 at $7000 \mathrm{rpm}$ for 14 minutes at $25^{\circ} \mathrm{C}$ to separate the solid phase.

In spray drying a first step is to evaluate if it is necessary use of carrier's agents. Priors tests indicating it is indispensable for protection from heat and facilitate its flow into the tower to prevente adherence of product to the equipment walls. The most commonly carrier used is the maltodextrin, a hydrolyzed starch widely that has a property of aiding the dispersion of a product and preventing its agglomeration pipelines. Maltodextrin DE10 (10\% equivalent dextrose) was mixed with GCP extract (7 oBrix) using an ultra turrex forming an emulsion to be atomized in a spray dryer. The percentage of maltodextrin was established according to the solids content of extract in this case 70 grams per liter of extract. The spray-drying process was performed using a laboratory-scale Mini Spray Dryer Buchi B-290 (Buchi Labortechnik AG). The emulsion was fed at a flow rate of $0.96 \mathrm{~L} / \mathrm{h}$, co-current air flow rate of $25 \mathrm{~kg} / \mathrm{h}$ and air inlet and outlet with temperatures of $170{ }^{\circ} \mathrm{C}$ and $90{ }^{\circ} \mathrm{C}$, respectively, $\mathrm{C}$, using a nozzle of $0.7 \mathrm{~mm}$ diameter. The powder product was stored into sealed metallic packaging and conserved at $25 \mathrm{oC}$ until the moment of analyses.

\subsection{Extraction of bioactives compounds of commercial products}


The extraction of bioactives compounds of the commercial products analyzed in this work followed the same procedures described in the section 2.2 only modifying the ratio mass/volum to $(0.067 \mathrm{~g} / \mathrm{mL})$.

\subsection{Determination of antioxidant capacity by ORAC}

The determination of antioxidant capacity by the Oxygen Radical Antioxidant Capacity, equation 1, was done according to Zulueta and colaborators [9] that consisted on the transfer of hydrogen from the antioxidant material (samples or trolox) to the AAPH radical [2,2'-azobis amidinopropane)], avoiding attacking the fluorescein present in the reactional medium. Samples were diluted in sodium phosphate buffer $\mathrm{pH} 7.4$ and transferred to a 96well microplate $80 \mu \mathrm{L}$. It was built a calibration curve, in triplicate, as well as the same amount of the samples besides the blank of the reaction, where $80 \mu \mathrm{L}$ of phosphate buffer was applied. The plate was taken to the Infinite 200 model Tecan Fluorimeter spectrum at $37{ }^{\circ} \mathrm{C}$ programmed with excitation wavelength of $485 \mathrm{~nm}$ and emission wavelength of 535 $\mathrm{nm}$. It was dispensed $80 \mu \mathrm{L}$ of fluorescein solution and performed the excitation e emition reading. After initial reading, it was dispensed $40 \mu \mathrm{L}$ of the AAPH radical solution and read excitation e emition of all wells at every 5 minutes for 90 cycles. The area under the curve (AUC) was calculated by software (Prism), using the fluorescence reading over the 90 cycles of the analysis. A trolox AUC values were subtracted from the blank AUC and the differences used for the construction of the Trolox calibration curve. The linear and angular coefficients obtained in the calibration curve were used to quantify the samples.

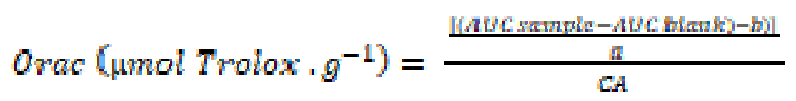

AUC sample = Area Under the Curve of the sample
AUC blank = Area Under the Curve of the blank
$\mathrm{b}=$ linear coefficient
$\mathrm{a}=$ angular coefficient
$\mathrm{CA}=$ Concentration of the sample in solution given in $\mathrm{mg} / \mathrm{L}$

\subsection{Determination of caffeine nd chlorogenic acid contents in GCP}

The determination of caffeine and chlorogenic acid were conducted in triplicates by HPLC Aliance 2695 with PDA detector 2996, with $280 \mathrm{~nm}$ and software Empower® (Waters, 
Massachusetts, EUA). The cromatographic column used was a BDS Hypersil C18 (5cm x 4,6mm e $3 \mu \mathrm{m}$ - Thermo Scientifc, Massachusetts, EUA), according Rosa and colaborators [10]. The quantification of both analytes were performed by external standardization base on calibration curves made with commercaial analitycal standards.

\section{Results and Discussion}

The results of antioxidant capacity determined by the ORAC methodology ranged from $33.02 \mu \mathrm{mol}$ trolox/g to $2,408.05 \mu \mathrm{mol}$ trolox/g, which shows the heterogeneity of the products (Figure 2). The range of antioxidant capacity of the GCE likely to be due to variation in the formulation of products containing other sources of compounds that exert antioxidant function [11]. The products 2, 3 and 5 showed low range of antioxidant capacity. The GCE supplement elaborated in this study (sample 10) showed an excellent antioxidant potential when compared to commercial green coffee products, besides presenting only coffee and maltodextrin in its formulation. Compared to 9 products analyzed, the product obtained in this work (Sample 10) presented third best antioxidant activity against commercial products.

Liang and colaborators [12] analyzed the antioxidant capacity of green arabic coffee beans from the Dominican Republic, Peru, Sumatra, Papua New Guinea and Ethiopia and obtained values of $410 ; 450 ; 420 ; 380$ and $410 \mu \mathrm{g}$ trolox equivalent/gram.

A great variation in the values of antioxidant capacity from GCP samples were observed, probably due to the different raw material, formulation and ways of processing to obtain each GCE. This information is emphatized through caffeine and chlorogenic acid results obtained by HPLC in our green coffee product. Since our GCP, sample 10, presented greated values for caffeine and clororogenic acid (Figure 3).

The antioxidant capacity of dietary supplements based on green coffee plays an important role which refer to quality of this products since the marketing of this products is around the antioxidant capacity. 


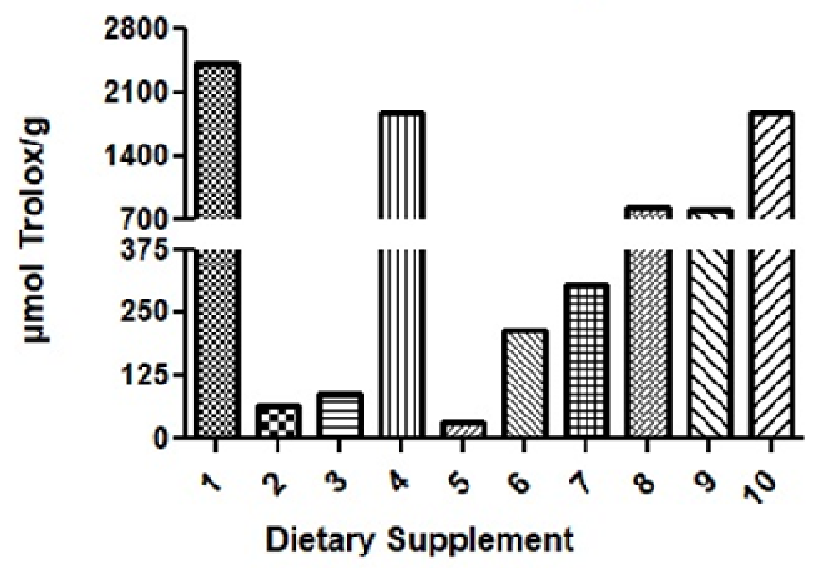

Figure 2. Antioxidant capacity of green coffee products
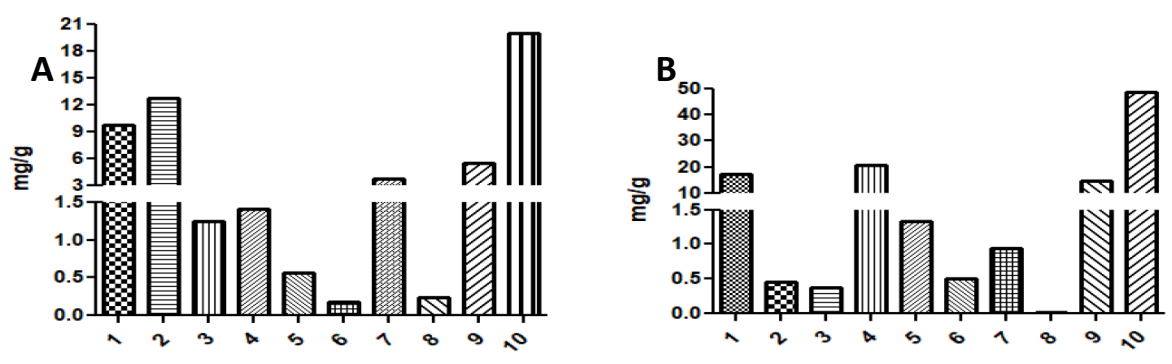

\section{Dietary supplement}

Figure 3. Caffeine (A) and chlorogenic acid (B) contents in green coffee products

\section{Conclusions}

A product of green coffee extract was elaborated in this work (Sample 10) with great antioxidant capacity . 
A great variation in the values of antioxidant capacity from GCP samples were observed, probably due to the different raw material, formulations and ways of processing to obtain each GCP.

The antioxidant capacity of dietary supplements based on green coffee plays an important role which refer to quality of this products since the marketing of this products is basen on their antioxidant activity.

\section{References}

[1]. Lima, A.R. et al. Compostos bioativos do café: atividade antioxidante in vitro do café verde e torrado antes e após a descafeinação. Química Nova, [s.1.], v. 33, n. 1, p.20-24, 2010. http://dx.doi.org/10.1590/s0100-40422010000100004.

[2]. Farah, A.; Santos, T.F. The Coffee Plant and Beans. Coffee In Health And Disease Prevention, [s.1.], p.5-10, 2015.. http://dx.doi.org/10.1016/b978-0-12-409517-5.00001-2.

[3]. Alves, R.C.; Casal, S.; Oliveira, B. Benefícios do café na saúde: mito ou realidade? Química Nova, [s.1.], v. 32, n. $\quad$ 8, p.2169-2180, 2009. http://dx.doi.org/10.1590/s0100-40422009000800031.

[4]. Gaascht, F.; Dicato, M.; Diederich, M. Coffee provides a natural multitarget pharmacopeia against the hallmarks of cancer. Genes \& Nutrition, [s.1.], v. 10, n. 6, p.1403-1409, nov. 2015. http://dx.doi.org/10.1007/s12263-015-0501-3.

[5]. Hendre, P.S \& Coffee (Coffea canephora Pierre Ex A. Froehner). Plos One, [s.1.], v. 9, n. 12, p.1-34, 2 dez. 2014. http://dx.doi.org/10.1371/journal.pone.0113661.

[6]. Dellalibera, O.; Lemaire, B.; Lafay, S. Svetol ${ }^{\circledR}$, green coffee extract , induces weight loss and increases the lean to fat mass ratio in volunteers with overweight problem. Phytoterapy, v. 4, n. 4, p. 194-197, 2006.

[7]. Farah, A. et al. Effect of Roasting on the Formation of Chlorogenic Acid Lactones in Coffee. Journal Of Agricultural And Food Chemistry, [s.1.], v. 53, n. 5, p.1505-1513, 2005. http://dx.doi.org/10.1021/jf048701t.

[8]. Liu, Q. M. et al. Optimization of ultrasonic-assisted extraction of chlorogenic acid from Folium eucommiae and evaluation of its antioxidant activity. Journal of Medicinal Plants Research, v. 4, n. 23, p. 2503-2511, 2010.

[9]. Zulueta, A.; Esteve, M. J.; Frígola, A. ORAC and TEAC assays comparison to measure the antioxidant capacity of food products. Food Chemistry, v. 114, n. 1, p. 310-316, 2009. 
[10]. Rosa J., Freitas-Silva O., Pacheco S., Godoy R., Rezende, C. LC-MS Based Screening and Targeted Profiling Methods for Complex Plant: Coffee a Case Study. Current Drug and Metabolisms. v. 13, p.1244-1250, 2012.

[11]. Costa, A.S.G. et al. Teas, dietary supplements and fruit juices: A comparative study regarding antioxidant activity and bioactive compounds. LWT - Food Science and Technology, v. 49, n. 2, p. 324-328, 2012.

[12]. Liang, N. et al. Interactions between major chlorogenic acid isomers and chemical changes in coffee brew that affect antioxidant activities. Food Chemistry, v. 213, p. 251$259,2016$.

\section{Acknowledgments}

We are very grateful to CAPES for scolarship for SOUZA, F.C.A. and FAPERJ for funding. 